\title{
Assessment of erosion dynamics on Marsa Matrouh coast, Western Egypt, using GIS and RS techniques
}

\author{
Ramadan Abd Elhamid Nofal* \\ ramadan_nofal@mans.edu.eg
}

\section{Abstract:}

The study area is a part of the north-west coast of the Mediterranean Sea in Egypt which extends to the west of Matrouh City for $15 \mathrm{~km}$ from Umm El-Rakham to Al Assi head. This region is characterised by a diversity of coastal landforms such as heads, bays, sand dunes, sharms, and others. Since some parts of this area has been subjected to severe erosion, the prevailing morphologic variables affecting the coastal landforms have been studied. The results confirmed the effective role played by the waves and the longshore currents in the development of the nearshore, foreshore and backshore, whereas the effect of wind is observed in the sand dunes area.

Remote sensing and geographic information systems methods have been used for detecting the changes in the coastal landforms, and in order to monitor these changes, two Landsat images separated by 33 years have been used. The results showed that the nearshore zone and the shore line are the areas subjected to the risk of erosion by the strength and speed of the shore currents. The change in land cover has also been observed in the backshore area. By comparing the tow DEMs with interval of 11 years, some landforms showed vertical changes especially sand dunes and Sharm areas.

Keywords: Geomorphology, Remote sensing and GIS, Coastal landforms, Morphologic variables, Erosion dynamics.

\footnotetext{
* Mansoura University, Faculty of Arts, Geography and GIS Department.
} 


\section{Introduction}

The coastal zone is one of the most dynamic areas on Earth, both on time and spatial scales. (Lira, C. and Taborda, R. 2014) .The remote sensing applications can be used in monitoring and analyzing the environmental problems (Asokan, A. and Anitha, J. 2019).

Remote sensing data provides great benefits to monitor the changes in coastal landforms. Moreover, land surface delineation and the interpretation of various features from satellite data are well documented for the effective management of natural resources (Magesh et al. 2014).

Timely and accurate change detection of the Earth's surface features provides the foundation for a better understanding of the relationships and interactions between human and natural features to better manage and use resources ( $\mathrm{Lu}$ et al. 2004). In general, change detection involves the application of multi-temporal data sets to quantitatively analyse the temporal effects of the features ( $\mathrm{Lu}$ et al. 2004; Mahmoudi, P. et al. 2020; Al-Rashidi, A. and Al-Hurban 2019; Badreldin, N, and Goossens, R. 2013; Shaban R. et al. 2019).

The aim of the recent study is to monitor the dynamic of coastal landforms in the nearshore area, the shoreline and the land cover in the backshore area by detecting the changes from tow Landsat images between them long period (33 years). DEMs data are also used to detect vertical change in main geomorphological units.

Finally, this study contributes to the understanding of geomorphological changes in coastal zones. It can also be considered as a geographical data base that contains useful measurements that can be relied upon when designing development plans, as it indicates areas that are exposed to erosion and the factors that cause it. Undoubtedly, 
this will be useful when designing development plans and searching for solutions to properly manage the coastal environment. (Skilodimou, H. et al. 2002).

\section{Study area}

The study area extends for $15 \mathrm{~km}$ along the coast between Ras Umm El-Rakham in the east and Ras Al Assi in the west (Fig. 1), lies between $31^{\circ} 26^{\prime} 40.51^{\prime \prime}-31^{\circ} 2 r^{\prime} 50.47^{\prime \prime} \mathrm{N}$ latitude and 26॰8'48.20"$27^{\circ} 4^{\prime} 23.50^{\prime \prime}$ E longitude, and is bordered to the north by the Mediterranean Sea and to the south by the interfluves line of wadis (Umm Ashtan - Habes - Umm El-Rakham - East and West Hash Magwa) (Fig. 3), which is part of the Miocene limestone plateau extending along the north coast.

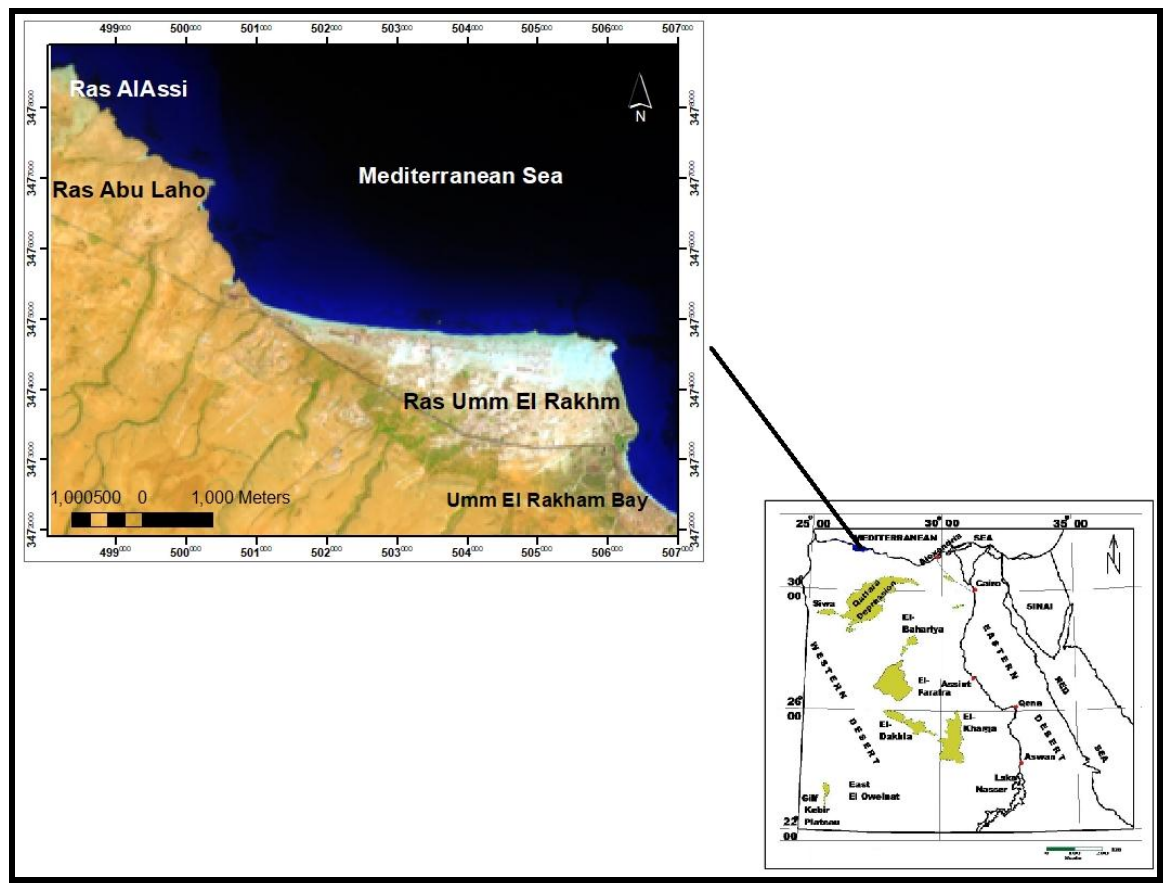

Fig. 1 Study area

( Assessment of erosion dynamics on Marsa Matrouh coast ...)Dr. Ramadan Nofal 


\subsection{Geology of the study area}

Geologically, the oldest exposed rocks in the study area belong to the middle Miocene (Third Era) (Fig. 2), and are of a form of limestone rich in fossils and marl, followed by the most prevalent Pleistocene formations that cover the most of the study area. The formations of this period appear in three main formations: pink limestone with an average thickness of 10 meters, shell limestone with an average thickness of 20 metres, and oolitic limestone with an average thickness of 20 meters, followed by the formations of the Holocene, which appear in the form of five formations: crust limestone, local deposits on the surface of the Miocene plateau, fluvial deposits, sandy deposits and finally beaches deposits (Trab, M. 1984).

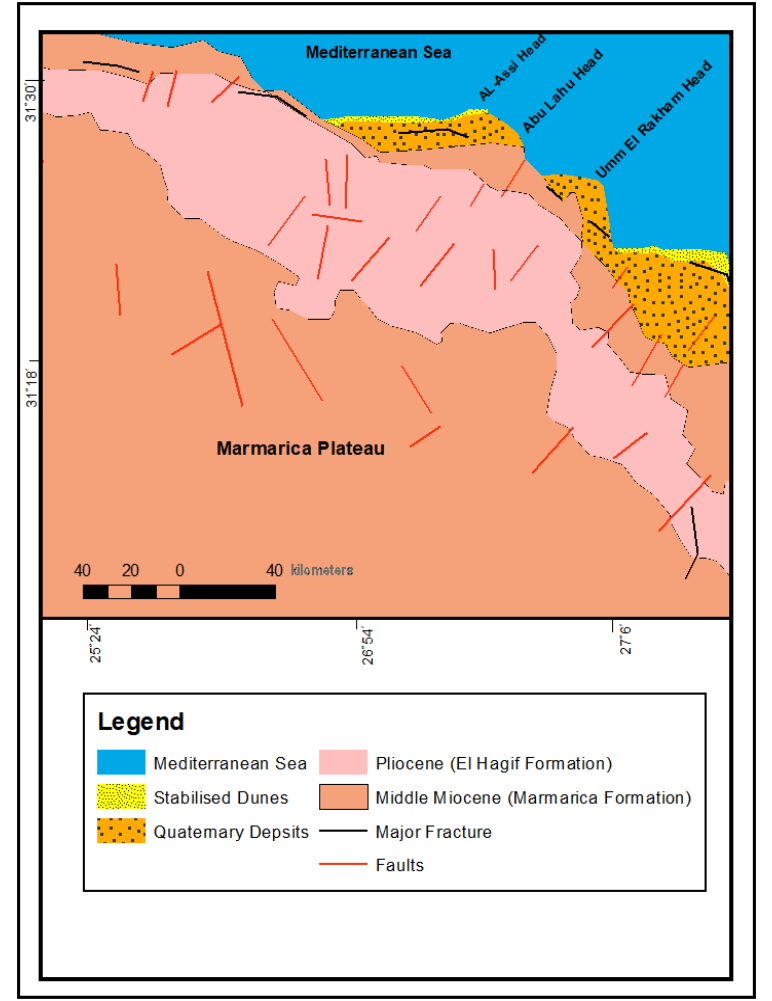

Fig. 2 The geologic units in the study area (after Conoco 1989) 
The geological layers in the study area are also affected by some geological structures due to exposure to tectonic lifting movements, where they were affected by two single-sided folds whose axis is heading northeast at Ras Umm El-Rakham and Ras Abu Lahu, and which are probably responsible for the emergence of these two heads as ground-bumps in the sea. These one-sided folds are confined between their axes to concave subsurface folds on their coasts, bays and coastal plains (Trab, M. 1984).

\subsection{Morphology of the study area}

The limestone plateau in the study area is characterised by the presence of five small wadis (Fig 3). The largest is the basin of Wadi Umm Ashtan at $115 \mathrm{~km}^{2}$, with stream order 4, followed by Wadi Umm El-Rakham which has an area of approximately $68 \mathrm{~km}^{2}$ and stream order 4. The smallest is Wadi Magwa at $4.5 \mathrm{~km}^{2}$ with stream order 2 (Table 1). In general, these wadis have a role in the development of the calcareous plateau, as well as in the coastal plain region, where some of these wadis outlets form small Sharms in the plateau cliff. Nofal, R. and Aboud, I. (2019) confirmed in their study the relation between the existence of these Sharm features and mountain wadis outlets. There are many of these Sharms in the study area, such as Sharm El-Assem in the area between Ras El Assi and Ras Abu Lahu, which seems full of sand accumulations, and Sharm Abu Lahu in the area between Ras Abu Lahu and Ras Umm ElRakham. This Sharm is the outlet of the Wadi (Western Hash) and the largest of them, and seems also to be covered by sand deposits. Finally, Agiba Sharm is also considered to be the outlet of the Wadi (Eastern Hash) (Fig. 4). 


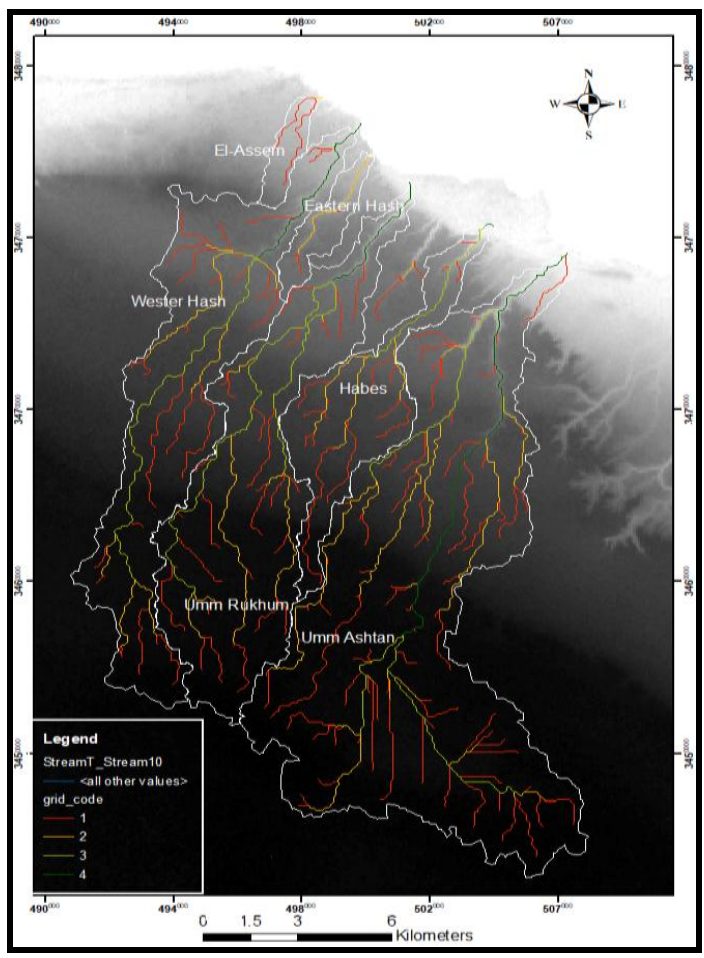

Fig. 3 Stream orders in study area basins

Table (1) Morphometric parameters computed for Wadis in the study area.

\begin{tabular}{|c|c|c|c|c|c|c|}
\hline parameters & Umm & Habes & Umm & Eastern & Western & Magwa \\
\hline Area km $^{2}$ & 115.7 & 24.3 & 68 & 14.4 & 51.3 & 4.5 \\
\hline Basin & 22908 & 14831 & 21412 & 10071 & 18679 & 4442 \\
\hline Perimeter m & 103383 & 49136 & 78532 & 34063 & 72660 & 14370 \\
\hline Stream Order & 4 & 3 & 4 & 2 & 4 & 2 \\
\hline Max stream & 28963 & 14847 & 30115 & 7578 & 25236 & 1456 \\
\hline
\end{tabular}

These Sharms are developed by water flow in the wadi outlets, which receive large amounts of precipitation in the winter due to the passage of the depressions, and by marine factors, where weak and medium waves enter the area of the Sharm loaded with sediments and deposit them. However, storm waves cause erosion processes, and the breaking of these waves produces lateral currents that cause lateral 
erosion and undercutting of the cliff, which leads to the landward expansion of the Sharms.

We mentioned before that the Miocene limestone plateau was subjected to two single-sided folds (Tarab, M. 1984), which led to the emergence of heads such as Umm El-Rakham - Abu Lahu- and El Assi. Between these heads there are bays formed within the concave folds, some of which, such as the Bay of Umm El-Rakham, are characterised by wide sandy beaches and the spread of white sand dunes, while some are less extensive, such as the bay of Ras abu Lahu and the bay of Ras El Assi.

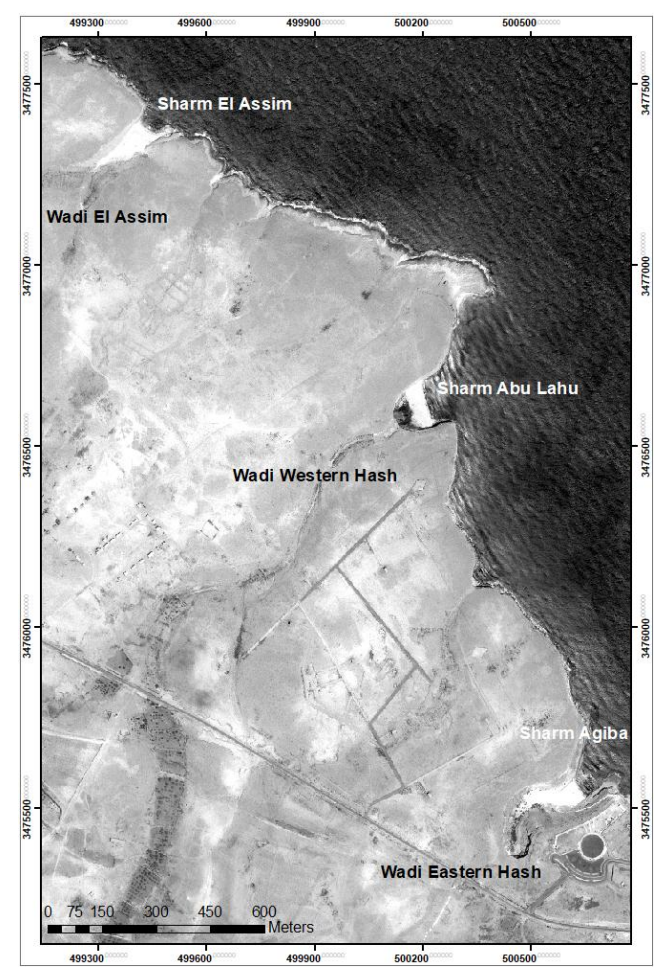

Fig. 4 Relationship between small sharms and wadis outlets

In the shallow water area, the sandy beaches disappear in the head areas, and an erosion platform appears, with the emergence of promontory rocks within the seawater, representing the remnants of 
erosion processes which take various forms, while in the bay areas the sediments cover the erosion platform, which shows residues as we move away from the shore.

\subsection{Morphological variables}

The coastal zone is not a stable and constant environment, but a dynamic place that can change rapidly in response to natural factors such as seasonal weather patterns. Waves, winds, currents, tides and storms are the major forces affect the coast. The results of the actions and interactions of these natural forces on the shoreline and near-shore seabed are called coastal processes. These include erosion and deposition, movement of dunes, longshore drift, and the effects of storms on the coastline (Page and Thorp 2010),

Wind: In addition to its influence on the marine factors (waves currents) and on the marine coastal dynamics, it plays an important role in the transit of sediments between the dunes and different beach zones. (Ayadi, K. et al. 2016).

The wind movement for a period of one-year is monitored by Beach Research Institute (2017) (Fig. 5). It is noted that the prevailing winds for $48 \%$ of the year are from the northwest with speeds of up to 16 meters per second, while the wind blows from the southwest direction for $26 \%$ of the year with speeds of up to 14 meters per second.

Waves: They are the most important force on sandy coasts because they transport sand on- and offshore and can also move sand along the shore (Beach Research Institute 2017). Wave-induced longshore currents are the main coastal process acting to cause morphologic changes in the littoral cells (Frihy, O. 2017). Storm waves are generated during January and February in winter, March and April in spring, and are linked to the movement of air depressions from west to east, while in the other month's construction waves 
prevail, which maintain the stability of coastal sedimentary forms along the coast. The waves movement for a period of one-year were monitored by (Beach Research Institute 2017) and show the dominance of the waves from the west and the northwest at a height of up to 5 metres in the storm periods. (Fig. 6).

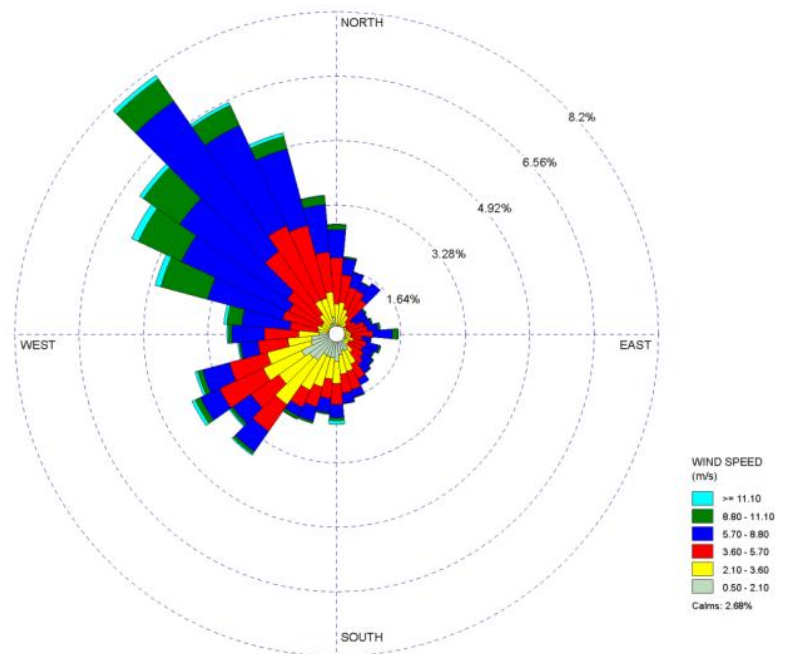

Fig. 5 Wind-rose for the study area (Beach Research Institute 2017)

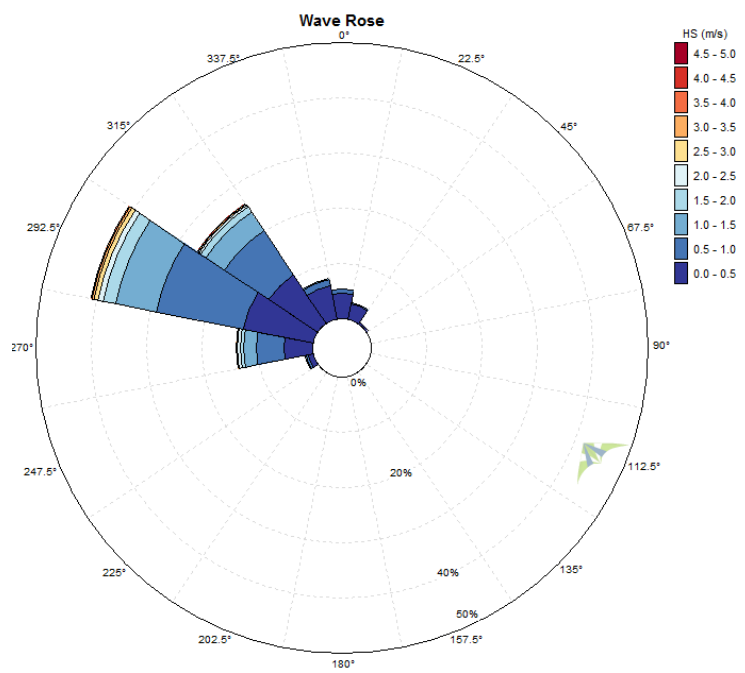

Fig. 6 Wave-rose for the study area (Beach Research Institute 2017)

( Assessment of erosion dynamics on Marsa Matrouh coast ...)Dr. Ramadan Nofal 
The Beach Research Institute has developed a model that shows the general pattern of the distribution of waves from different directions. The maximum height waves reaching the shoreline range from $1.65-0.5 \mathrm{~m}$ from the northwest direction, and it should be noted here that the waves generated in the offshore area were initially more than 5 meters high, but their entry into the near-shore area and their interaction with the submerged rocks and small rocky islands in the shallow water made them break and decrease in height (Fig. 7).

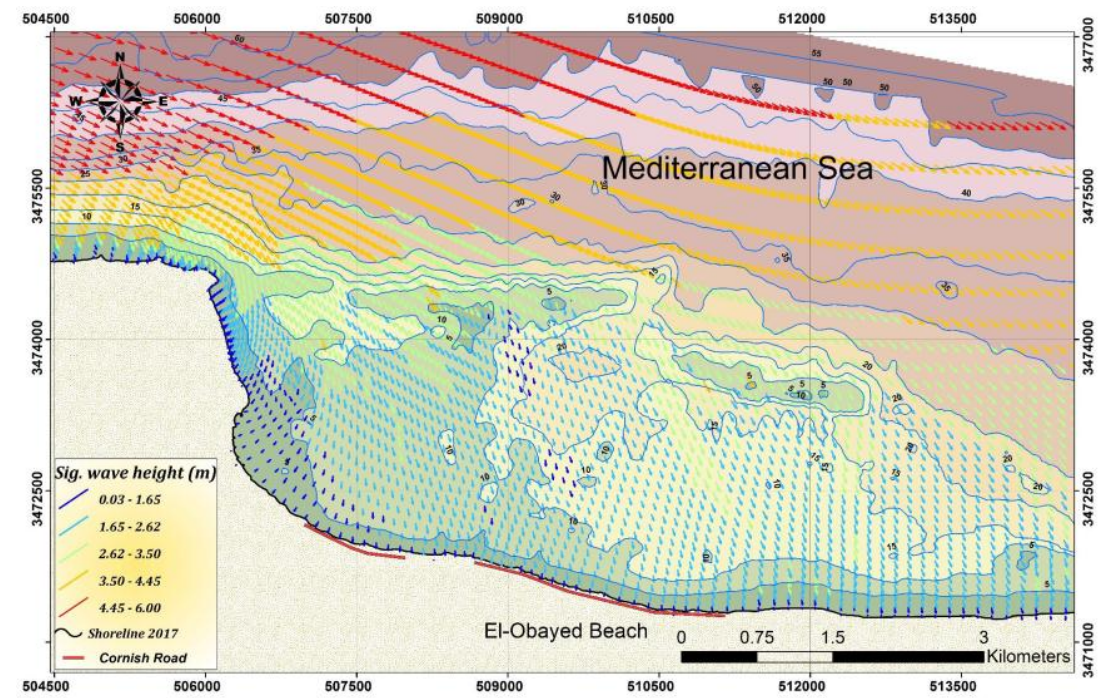

Fig. 7 The general pattern of waves distribution (Beach Research Institute 2017)

Coastal Currents: These currents may transport large amounts of sand and alter the shape of offshore sandbars. Longshore currents (longshore drift) occur when the waves come in at a slight angle to the shoreline. Fig. 8 shows the general pattern of the distribution of beach currents along the study area (Beach Research Institute 2017). The western part of the study area is characterized by the presence of a high-speed eastern current up to $1.5 \mathrm{~m} / \mathrm{s}$ when the waves are in their extreme case from the northwest direction. This speed drops to 0.4 in 
the case of normal waves, while the eastern part of the study area is characterized by a moderate current of $1.0 \mathrm{~m} / \mathrm{s}$ to $0.2 \mathrm{~m}$ in normal waves.

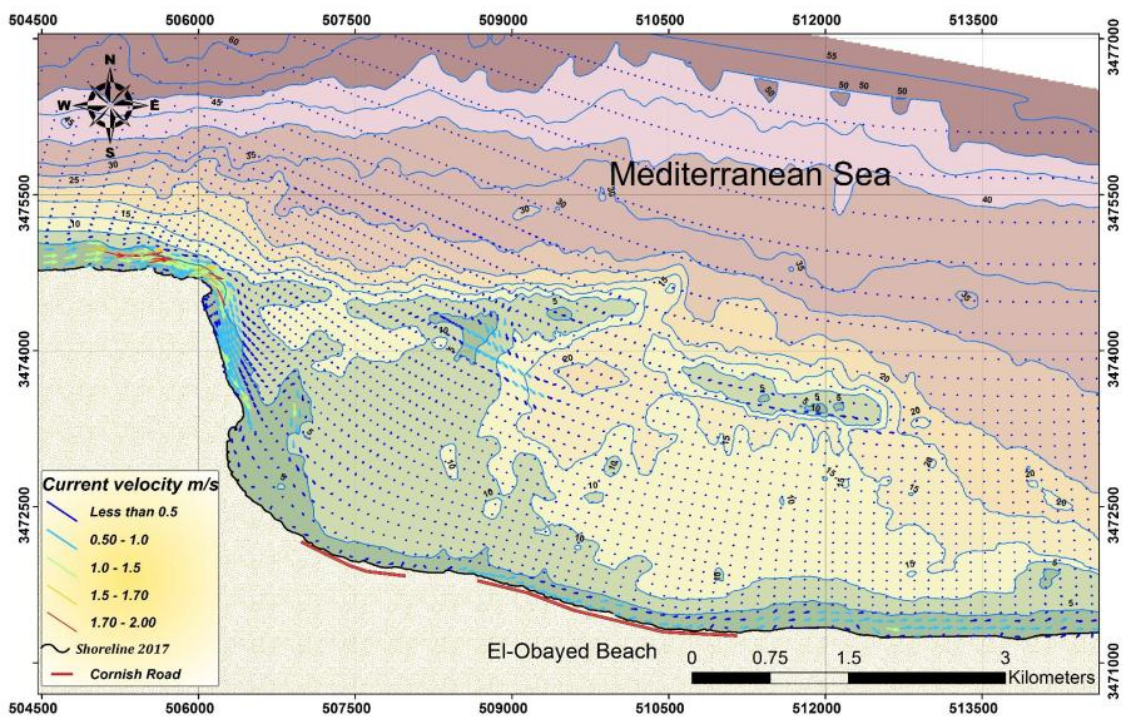

Fig. 8 The general pattern of the beach currents distribution (Beach Research Institute 2017)

\section{DATA USED AND METHODOLOGY}

In this study, the integration of geographic information systems and remote sensing was used to classify coastal morphological features and monitor their geomorphological development, based on various data (Table 2) in addition to repeated field observation in the study area.

Table (2) Data used and sources

\begin{tabular}{|l|l|l|l|l|}
\hline Data source & Resolution $(\mathbf{m})$ & Path/Row & Date & Time \\
\hline Landsat 5 TM & $\mathbf{3 0}$ & $\mathbf{1 7 9 / 0 3 8}$ & $\mathbf{3 0 / 1 2 / 1 9 8 4}$ & $\mathbf{0 7 : 3 7 : 0 0 . 0}$ \\
\hline Landsat $\wedge$ LOI & $\mathbf{3 0}$ & $\mathbf{1 7 9 / 0 3 8}$ & $\mathbf{1 5 / 0 5 / 2 0 1 7}$ & $\mathbf{0 7 : 5 4 : 1 1}$ \\
\hline SRTM 3 & $\mathbf{9 0}$ & $\mathbf{1 7 9 / 0 3 8}$ & $\mathbf{1 1 / 0 2 / 2 0 0 0}$ & \\
\hline Aster & $\mathbf{3 0}$ & & $\mathbf{1 5 / 1 0 / 2 0 1 1}$ & \\
\hline Topographic map & $\mathbf{1 / 5 0 0 0 0}$ & & $\mathbf{1 9 8 3}$ & \\
\hline Geological map & $\mathbf{1 / 5 0 0 0 0 0}$ & & $\mathbf{1 9 8 6}$ & \\
\hline
\end{tabular}


Various types of spatial data sources such as topographical maps, Landsat 5 TM images $(30 \mathrm{~m})$ acquired in 1984 and Landsat 8 OLI (30 m) acquired in 2017, Aster (30m) and SRTM (90) DEM were used.

Topographic maps were used when classifying the Landsat images and detecting changes in the land cover. The Landsat images were used to detect changes in the shoreline and nearshore area, and SRTM 3arc-second and Aster data were used to detect vertical change in some zones to see the degree of their development. All of these data went through a series of processors via ArcGIS-ENVI-Global Mapper software, while Garmin ETREX 3.0 was used to take many ground control points and use them as the training area when making a supervised classification, as well as when adjusting the error in the SRTM and Aster data.

\subsection{Image and preprocessing}

Accurate per-pixel registration of multi-temporal remote sensing data is essential for change detection since the potential exists for registration errors to be interpreted as land cover and land-use change, leading to an overestimation of actual change (Stow 1999). Change detection analysis is performed on a pixel-by-pixel basis, so any misregistration greater than one pixel will provide an anomalous result for that pixel.

Geometric correction of (Tm and OLI) satellite images was performed by a set of GPS control points and assigned to UTM geographic projection Zone 35, then a radiometric correction was done and the images were filtered and enhanced to get the best results. Finally, the output of Landsat was reled to $15 \times 15 \mathrm{~m}$ by pixel. 
Radiometric correction was done where the digital numbers (DNs) registered by the sensor were converted to a satellite radiance using calibration coefficients supplied by the meta data file of the Landsat satellite. After getting the radiance of the respective spectral bands, these are converted to the Top of Atmosphere Spectral Reflectance, which will be used in index and the bathymetry analysis (Pattanaik et al. 2015)

The DEMs data (Table 2) is different in spatial resolution and therefore cannot be used to show the change only after correcting, so the ENVI program was used in the standardization of the spatial resolution to 30 meters per pixel, in addition to which they were reassigned to UTM projection after being corrected with many of the ground control points obtained by GPS. As a result, the RMSE in the SRTM data became 3.1 meters compared to the global standard of 16 meters and the ASTER data became 4.6 meters compared to 25 meters on a global scale (Milan et al. 2011). Therefore, the RMSE of both DEMs is reasonably good for Geomorphic Change Detection, if not with the expected precision, and a clear differentiation is possible, which is indicative of geomorphic changes (Kaliraj et al. 2014). Finally, the output DEMs are resampled to $1{ }^{\circ} \times 1^{\circ} \mathrm{m}$ pixels, to integrate their data with the Landsat images as well as using them as a guide when making classifications. It should be noted that after all these operations the DEMs data model retains the same features as the original cells (Mujaber, S.P. and Chandrasekar, N. 2011). 


\subsection{Shoreline mapping and change rate calculation}

The water index method was used to determine the shoreline. The NDWI index (Normalized Difference Water Index) is most appropriate for water body mapping. The water body has strong absorbability and low radiation in the range from visible to infrared wavelengths. The index uses the green and near infra-red bands of remote sensing images based on this phenomenon. The NDWI can enhance the water information effectively in most cases. It is sensitive to built-up land and often results in over-estimated water bodies (McFeeters 1996). On the NDWI maps, dark colors (values close to -1) represent a surface without plants or water content; lighter areas represent land with moisture content (values close to 0) and with water bodies (values close to +1) (El-Hadidy, S. 2020)

In the ENVI environment the water index was used to get the shoreline, and export it as a vector layer to the ArcGIS environment to get the change of shoreline from 1984 to 2017 using the DSAS digital shoreline analysis system developed by (Thieler et al. 2017).

This extension (DSAS) contains three main components that define a baseline, generate orthogonal transects at a user-defined separation along the coast, and calculate rates of change (Net Shoreline Movement, linear regression, endpoint rate, etc.) (Jana et al. 2013). Based on our setting, the DSAS program generates 128 transects that are oriented perpendicular to the baseline at $100 \mathrm{~m}$ intervals along the shore (Fig. 9). 


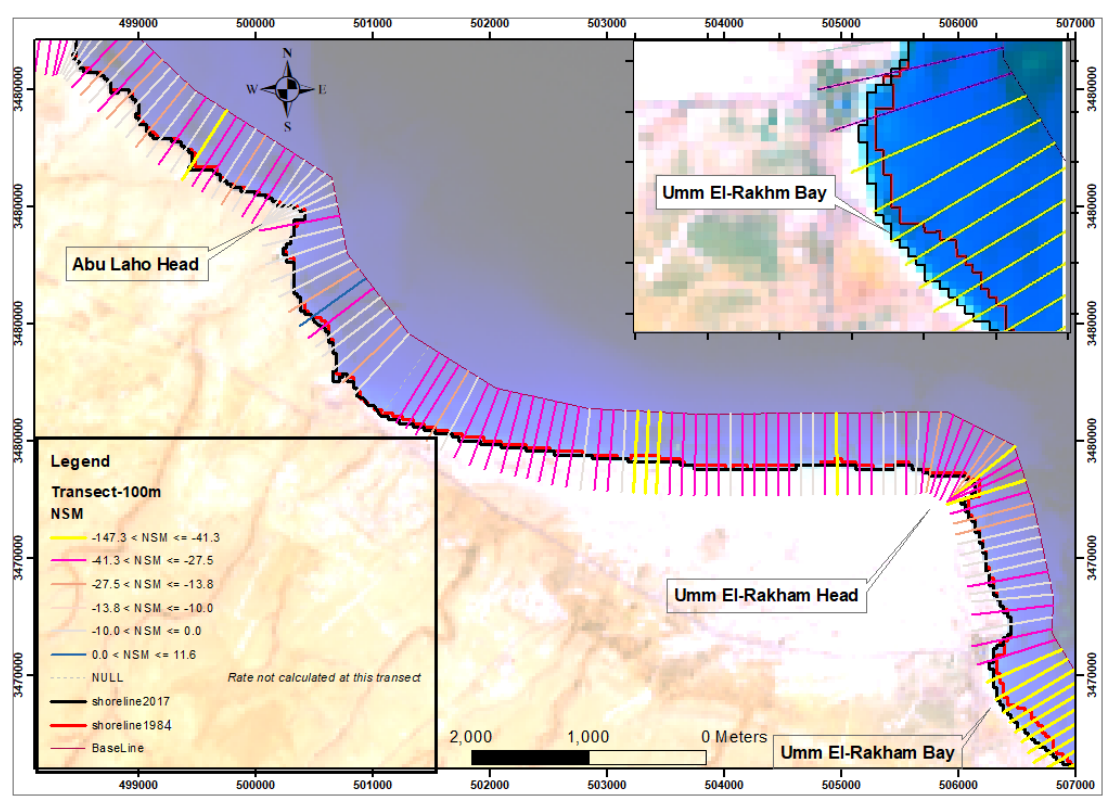

Fig. 9 Transects generated by DSAS for shoreline change detection

\subsection{Depth estimation}

Many empirical models and radiative transfer equations that are used to derive the water depth from remotely sensed data have been proposed and evaluated for bathymetric estimations by establishing the statistical relationship between the image pixel values and fieldmeasured water depth values (Pattanaik, A. et al. 2015). ENVI software was used to retrieve the bathymetric map from Landsat 8OLI (Fig. 10). The Relative Water Depth tool enables the user to quickly generate a product depicting relative water depths for a region of interest. This tool uses a bottom albedo-independent bathymetry algorithm developed by (Stumpf, P. et al. 2003). 


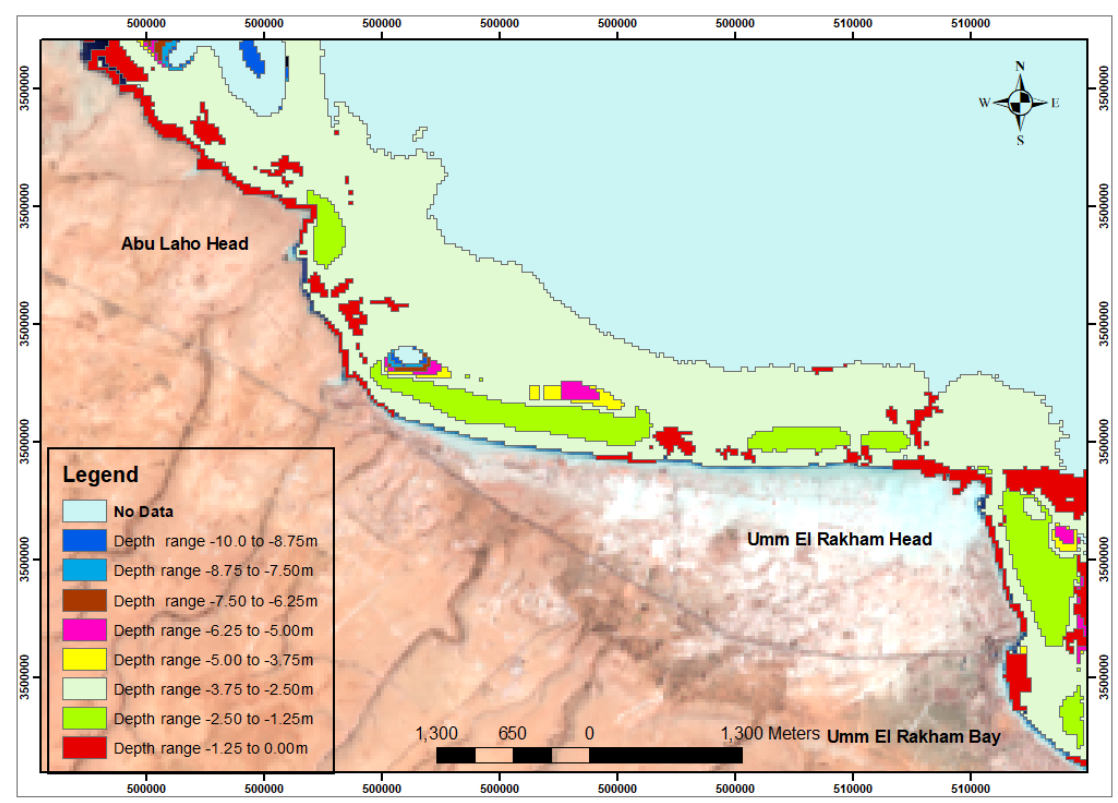

Fig. 10 Density colour slice to classify image in depth ranges from 0 to $10 \mathrm{~m}$ by $\log$ ratio method.

\subsection{Submerged rock mapping and change calculation}

Different enhancement methods were used to show the shallow water features and then the land area masked. Using the spectral analysis methods, the submerged rock areas were determined to define their impact on coastal erosion processes in the study area, and finally to detect the change occurring in them in the period from 1984 to 2017.

\subsection{Land cover change}

The LANDSAT images, with the help of GPS, topographic and geological maps, were subjected to a supervised classification using a parallel probability algorithm, to detect changes in land cover in the study area and various geomorphological features, especially sand dune areas. 
It should be noted that the integration of DEMs data with satellite images greatly helps to identify some coastal features (Blanchard et al. 2010), especially while conducting classification processes, from which different geomorphological units such as sand dunes, cliffs, and headlands can be identified.

\subsection{Cross-shore profile change detection}

SRTM and Aster data will be used to detect the vertical change occurring in the coastal zone, where GIS allows analysis of the detection of volumetric change in geomorphological features using DEM data with an appropriate time interval (James et al. 2012).

DEMs data are recorded as bitmap data, where each cell has elevation values for its position on the Earth's surface, so DEMs data are used worldwide for the visualization of 3D terrain and hydrological modelling and measurement of geomorphological changes (Blanchard et al. 2010; Fabris and Pesci 2005; Siart et al. 2009; Marghany et al. 2010).

We noted before that the DEMs were processed with ENVI software, and then transferred to the global mapper environment, and a baseline was identified as a contour line of $30 \mathrm{~m}$ to represent the beginning of drawing a range of sectors (Fig. 11). Each sector intersects with two DEMs at the same time, so a graph produces two curves, each expressing its digital elevation model. These curves are easy to compare and therefore detect vertical change through them.

The location of the sectors was carefully selected to detect the change in the main geomorphological units, and the researcher tried as much as possible to avoid areas crowded with urbanization in order 
not to affect the detection of the change in the natural appearance, although sometimes it is not possible to avoid the effect of the spread of urbanization, and this undoubtedly affects the results.

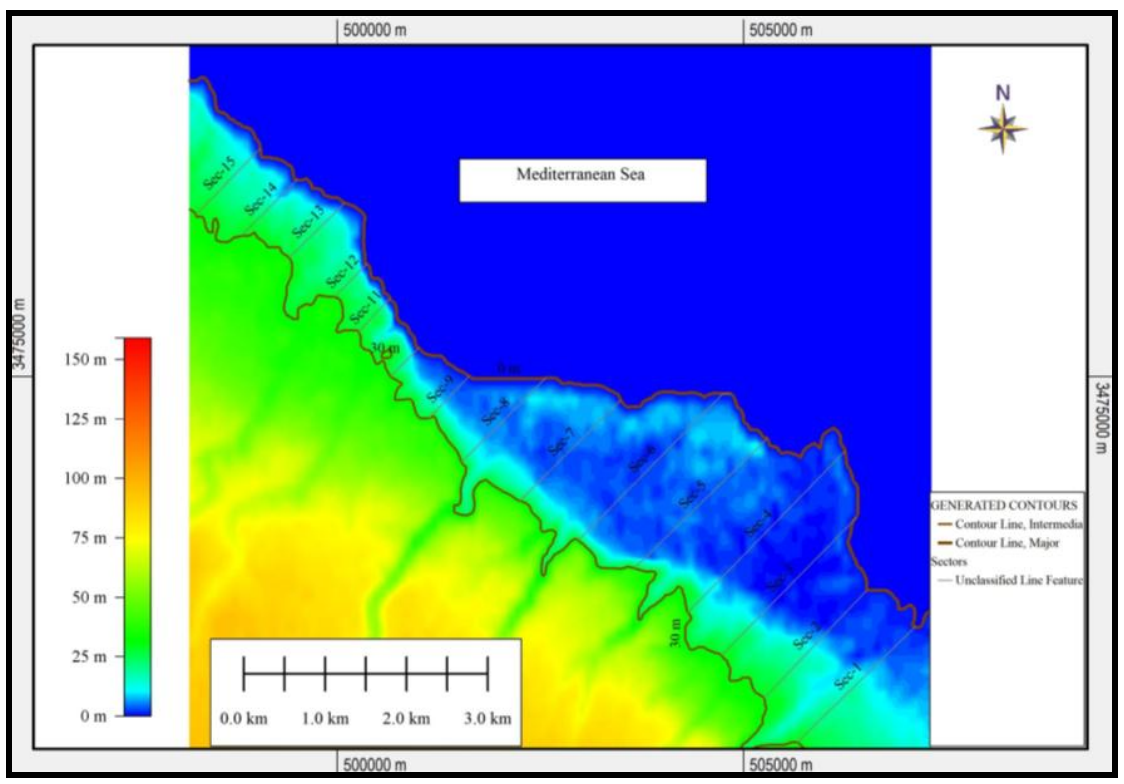

Fig. 11 Sector positions on DEMs

\section{Results and Discussion}

The study is based on three axes: the first is the change in the shoreline to identify areas that are subject to the erosion process and others that are exposed to the deposition process; second is the change in land cover where the change in the areas of land cover units is monitored; third is the vertical change through the data of DEMs. The study area is divided between headlands and bay regions. It is assumed that the headlands extending into the sea are more susceptible to being eroded by waves as their extension into the sea makes them deeper than other nearby coastal areas, and this means waves breaking on them with a higher intensity, leaving them more exposed to marine erosion (Nofal, R. and Abboud, I 2016). By 
contrast, if the headland is a cliff plunging straight into deep water, the waves do not break before they strike and cause little erosion (Huggett 2011).

There are other factors that cannot be ignored when discussing this issue, including the direction of the head and how it corresponds to the waves, as well as the topography of the bottom in front of the head, and other factors related to the direction and height of the waves, as well as the effect of the beach currents resulting from the refraction of these waves.

Concerning bay areas where sand accumulates, which are vulnerable to coastal erosion processes particularly in the central areas due to waves. The breaking of the waves entering the bay results in lateral currents that can transport disjointed sediments and re-establish them at the edges of the bay regions.

Here, the study of the shoreline is useful to identify areas that are exposed to erosion and deposition, due to marine factors in order to understand their behaviour, whether in the areas of heads or bays.

Shoreline changes from 1984 to 2017 were studied from two Landsat images, using the Dash tool within the ArcGIS environment, where 180 sectors were stretched along the coast from baseline to shoreline. Most sectors recorded a decline in the shoreline, with a few sectors recording minor deposits (Fig. 9).

The eastern part of the study area, specifically the coast of Umm El-Rakham Bay (Fig. 9), recorded the most retreats due to the marine erosion process, as a result of fast shore currents in this area, and a retreat of about $-147 \mathrm{~m}$ was recorded in the period from 1984 to 2017, with an annual average of $-4.6 \mathrm{~m} / \mathrm{y}$. The areas of heads also recorded retreats of about $-38 \mathrm{~m}$ in the same period, due to the waves (Fig. 7), 
and the presence of fast beach currents (Fig. 8). This can be explained from the depth map (Fig. 10), where it can be noted that shallow depths ranging from 0 to $1.25 \mathrm{~m}$, which often surround the shore line, also appear in the deepest region, where the depth generally ranges from 3.75 to 5 metres. This means that there are submerged rock areas that are still resisting erosion processes, and cause waves to break before they reach the shore, and reduces their impact on the heads.

So these rocks were determined from the Landsat images and revealed the change in this feature in the period from 1984 to 2017 (Fig. 12 and 13), from which it is clear that the area of the heads is largely protected from the impact of marine factors, and parts of these rocks can be seen prominently during the ebb periods. The measurement of the change in the bottom rocks revealed their exposure to erosion and retreat, where about $0.36 \mathrm{~km}^{2}$ were eroded in the period from 1984 to 2017 (Table 3).

The study of land cover change detection (Fig. 12, 13 and Table 3) shows that there is rapid urban development in the region, where the area of urbanization increased from $3.2 \mathrm{~km}^{2}$ in 1985 to $6.9 \mathrm{~km}^{2}$ in 2017, which means an increase in this area of about $3.7 \mathrm{~km}^{2}$, doubling the urbanized area. It should be noted that, human activities, resource use and urban development in coastal areas often have long-lasting effects, such as increasing hazard vulnerability and environmental degradation (Alharbi, O. et al. 2017)

The area of cultivated land increased from $7.09 \mathrm{~km}^{2}$ in 1984 to $7.53 \mathrm{~km}^{2}$ in 2017 , an increase of $0.44 \mathrm{~km}^{2}$. The area of the dunes shrank and decreased from $4.57 \mathrm{~km}^{2}$ in 1985 to $4.04 \mathrm{~km}^{2}$ due to their exposure to marine erosion in the bay areas, as well as the removal of some of them for the establishment of urban areas, and the role of the 
north and north-west winds in the transport of sand deposits from the coastal area to the land side. The North coastal region of Egypt is exposed to significant spatial and temporal changes in LCLU classes (urban, agriculture, and sand dunes) that basically affect any kind of development programs. (Khafagy, $M$ et al. 2020)

The study of vertical change through DEM data gives another idea of the relationship between the occurrence of erosion processes and the characteristics of the coastal area, and was based on the definition of a contour line of 30 metres as a baseline, then drawing 15 sectors ending at the oldest shoreline (Fig. 11). The researcher tried as much as possible to avoid the areas where urbanisation is spreading so as not to affect the results of the study.

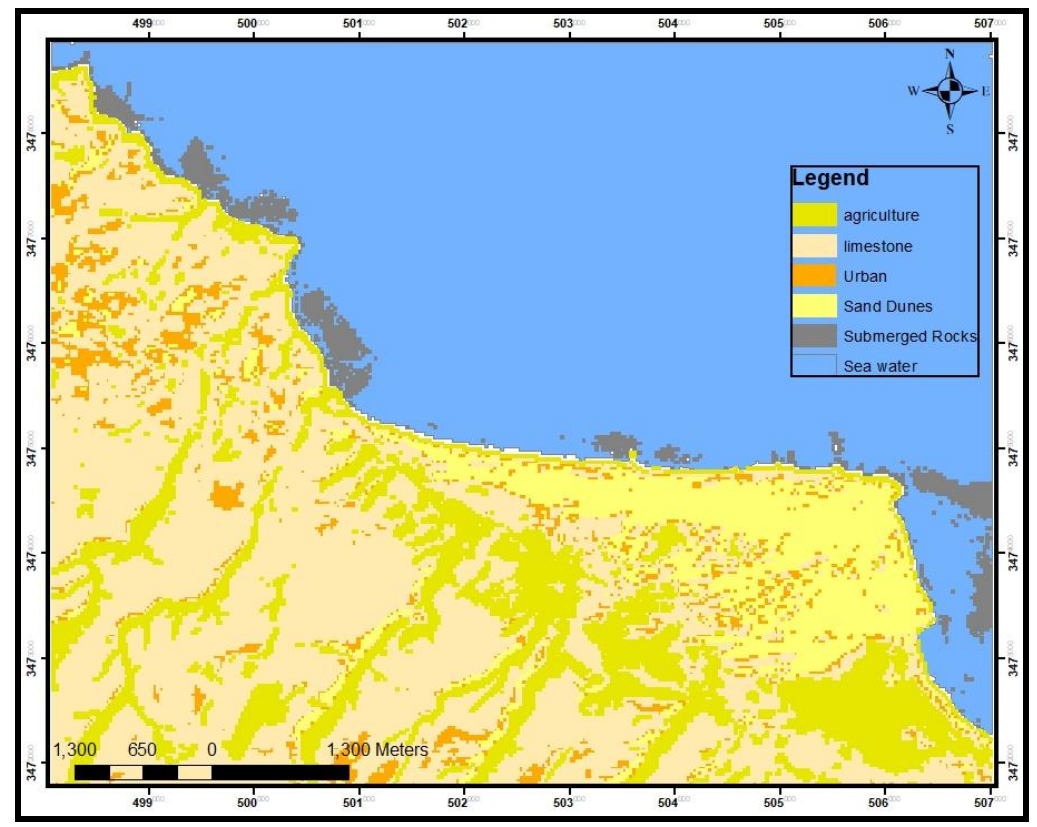

Fig. 12 Land cover classification of the study area in 1984 


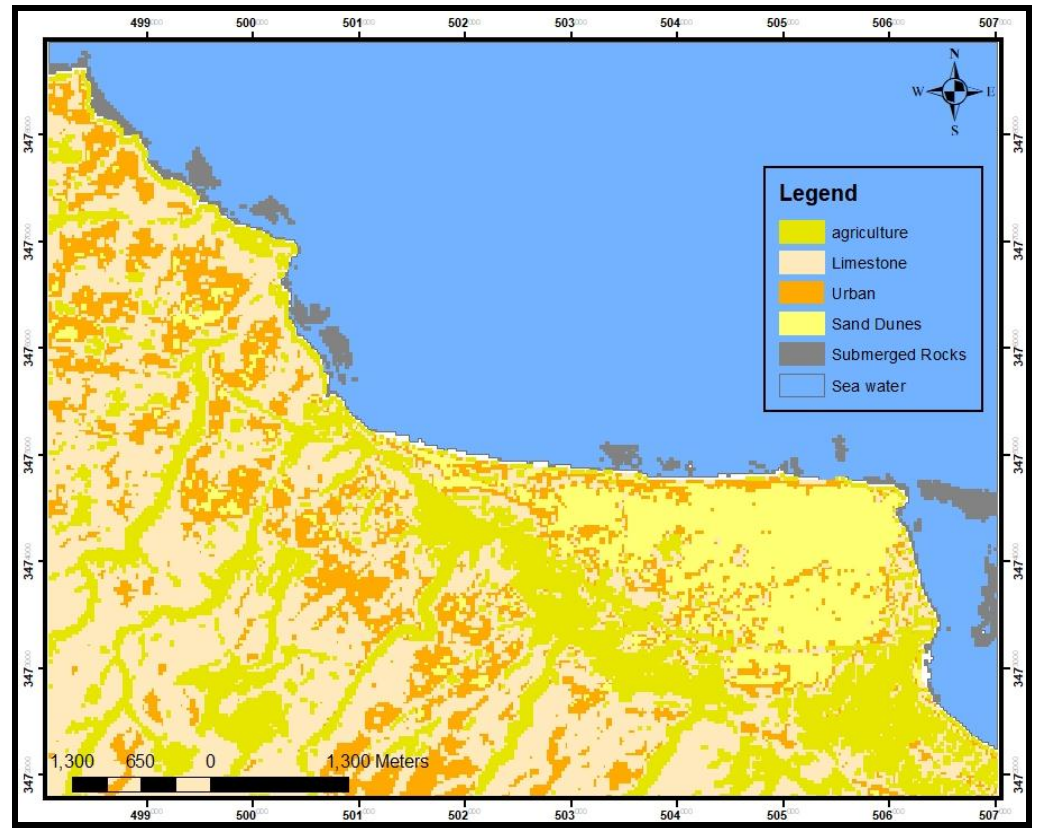

Fig. 13 Land cover classification of the study area in 2017

Table (3) Land Cover Change Detection in the period from 1984 to 2017

\begin{tabular}{|c|c|c|c|}
\hline Land Cover & $\begin{array}{c}\text { Landsat TM } \\
1984\end{array}$ & Landsat OLI 2017 & Change/ km ${ }^{2}$ \\
\hline $\begin{array}{c}\text { Cultivated Land/ } \\
\mathbf{k m}^{2}\end{array}$ & 7.09 & 7.53 & $0.44(+)$ \\
\hline Urban Area/ km² & 3.22 & 6.92 & $3.70(+)$ \\
\hline Sand Dune/ km² & 4.57 & 4.04 & $0.53(-)$ \\
\hline $\begin{array}{c}\text { Submerged Rock/ } \\
\text { km }^{2}\end{array}$ & 1.25 & 0.89 & $0.36(-)$ \\
\hline
\end{tabular}

Fig. 14 shows the cross-shore profile change detection, and it was noted that sectors 1 to 4 indicate the accumulation of sediment, especially in the lower coastal areas near the sea. Here we must note that this area is the same one that was previously proved to be subject to large retreats when conducting the change detection in the shoreline (Fig. 9), and this explains the contradiction between the finding that this area is characterized by the presence of sand dunes, which are 
subject to marine erosion process, but also exposed to the the accumulation sediments transported from the shore area by the prevailing north and northwest winds.

Some sectors were drawn to go through the features of sharms to identify the change that occurs. Sector 10 has been drawn within Sharm Agiba, where it is seen that the lower part is exposed to deposition, as shown by the sand accumulations in the upper part, which indicates that the plateau region is exposed to erosion by various factors, including torrential runoff in winter and marine factors in times of storms. Also, in sector 14, which passes through Sharm El-Asim, indicates that it is the lower part is exposed to deposition. Here, it should be noted that the accumulated sand inside the sharms is the result of the waves entering the sharm loaded with sand which then become less powerful and precipitate the sand within the foreshore area.

The study of the sectors that cover the cliff areas in the plateau of Agiba and Ras Abu Lahu (10, 11 and12) indicate that they are exposed to the erosion process. Thus, the study of change sectors using DEMs has helped to understand the behaviour of the erosion processes in the region and determine their location, making it possible thus to find ways to counter them.

Finally, the results of the study conclude from the different methods used that there are harsh erosion processes to which some parts of the study area are exposed. The region needs intervention by the responsible authorities to address the dangers resulting from erosion and to protect the region from human impacts that may contribute to the aggravation of the problem, especially as new roads 
have been built in the Umm El-Rakham Bay area less than $100 \mathrm{~m}$ from the shoreline.

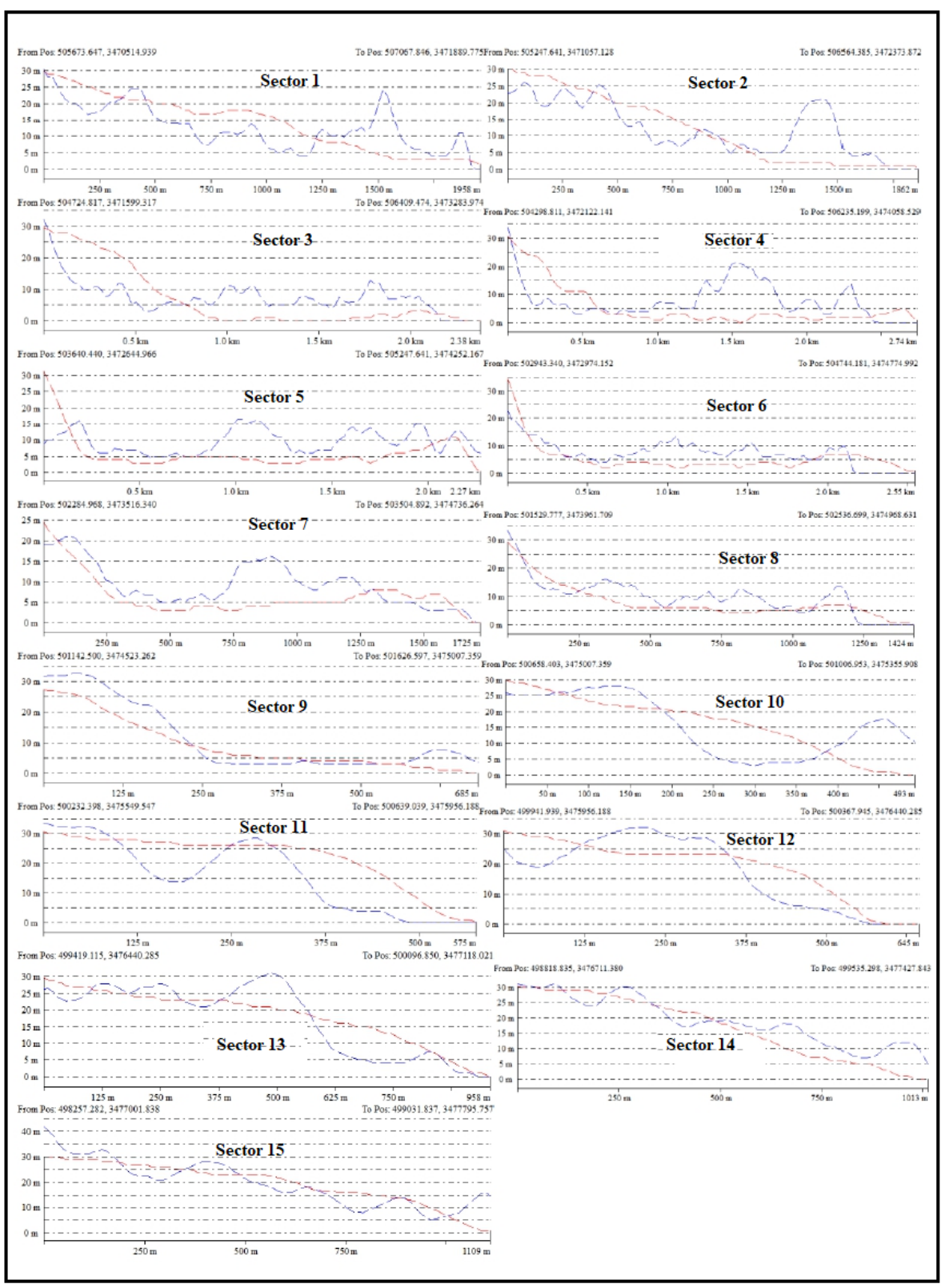

Fig. 14 SRTM and ASTER DEMs extracted cross-shore profile change 


\section{Conclusion}

The study concludes that there are coastal erosion processes prevailing in the study area that appear to be dangerous in the bay areas with white sandy beaches, which are considered among the most beautiful beaches in the world,

The study of shoreline changes confirmed that the decline and erosion are increasing in the bay areas between the heads, which are also exposed to erosion but to a lesser extent than the sandy beaches. The study of the change in the submerged rocks also gave an explanation of the impact of marine factors in bay areas compared to the head areas.

The study of land cover change detection gave a clear picture of the change in the different geomorphological units, the most important of which was the doubling of the area of urbanisation, which is concentrated near the coastal areas, as indicated by a decrease in the area of sand accumulations, which will return negatively on the area of good beaches for human use.

Finally, the study of cross-shore profiles change detection that were done based on DEMs of different dates completed our knowledge of all the forms of change taking place in the region and allowed accurate identification of the changes in the cross-shore profile.

In general, the results of the study confirm that there are risks resulting from coastal erosion, which appear in the form of rapid erosion on some beaches, which needs attention from the responsible authorities in order to determine the best method to prevent this danger. 


\section{References}

1- Alharbi; O.; Michael, R.; Phillips; Allan, T.; Williams; Thomas, T.; Hakami, M.; Kerbe, J.; Niang, A.; Hermas, E. and Al-Ghamdi, K. (2017) Temporal shoreline change and infrastructure influences along the southern Red Sea coast of Saudi Arabia. Arab J Geosci 10:360 https://link.springer.com/article/10.1007/s12517-017-3109-7

2- Al-Rashidi, A. and Al-Hurban, A. (2019) Geomorphological changes along the coastline of As Sabriya, northern Kuwait. Arabian Journal of Geosciences 12: 290 https://link.springer.com/article/10.1007/s12517-019-4466-1

3- Asokan, A. and Anitha, J. (2019) Change detection techniques for remote sensing applications: a survey. Earth Science Informatics (2019) 12:143-160. https://doi.org/10.1007/s12145-019-00380-5

4- Ayadi, K.; Boutiba, M.; Sabatier, F. and Guettouche, M. (2016) Detection and analysis of historical variations in the shoreline, using digital aerial photos, satellite images, and topographic surveys DGPS: case of the Bejaia bay (East Algeria). Arab J Geosci 9: 26 https://link.springer.com/article/10.1007/s12517-015-2043-9

5- Badreldin, N. and Goossens, R. (2013) Monitoring land use/land cover change using multi-temporal Landsat satellite images in an arid environment: a case study of El-Arish, Egypt. Arab J Geosci 7:16711681

6- Beach Research Institute (2017) Project of studying the protection of El-Obied beach area Marsa Matrouh to achieve sustainable development. Unpublished study in Arabic.

7- Blanchard, D.; Rogan, J. and Woodcock, W. (2010) Geomorphic change analysis using ASTER and SRTM digital elevation models in central Massachusetts, USA. GISci.Remote Sens 47 (1): 1-24. https://www.tandfonline.com/doi/abs/10.2747/1548-1603.47.1.1

8- Conoco (1989) Geological map of Egypt, scale 1:500000.

9- El-Hadidy, S. (2020) Monitoring shoreline changes and aeolian sand encroachment, Nasser Lake, Egypt, using remote sensing and GIS techniques. Arabian Journal of Geosciences 13: 1285

10-Fabris, M. and Pesci, A. (2005) Automated DEM extraction in digital aerial photogrammetry: precision and validation for mass movement monitoring. Ann Geophys 48:973-988.

https://www.annalsofgeophysics.eu/index.php/annals/article/view/324 7 
11-Huggett, R. (2011) Fundamentals of Geomorphology, $3^{\text {rd }}$ edn. Routledge, UK.

https://sudartomas.files.wordpress.com/2012/11/fundamentalsofgeom orphology_routledgefundamentalsofphysicalgeography.pdf

12-Kaliraj, S.; Chandrasekar, N.; Magesh, S. (2014) Multispectral image analysis of suspended sediment concentration along the Southern coast of Kanyakumari, Tamil Nadu, India. J. Coastal Sci. 1 (1), 63-71.

13-Khafagy, M.; El-Sayed, H. and Darwish, K. (2020) Land cover/use change analysis and mapping of Borg El-Arab City, Egypt. Arabian Journal of Geosciences 13: 1123

https://link.springer.com/article/10.1007/s12517-020-06115-x

14- Keller, E. (1996) Environmental Geology. $7^{\text {th }}$ edn. Prentice Hall.

15-James, A.; Hodgson, E.; Ghoshal, S. and Latiolais, M. (2012) Geomorphic change detection using historic maps and DEM differencing: the temporal dimension of geospatial analysis. Geomorphology 137:181-198.

https://people.cas.sc.edu/hodgsonm/Published_Articles_PDF/James_Hodgso n_Ghoshal_Latiolais_DEM\%20DIfferencing_Geomorphology2012.pdf

16- Jana, A.; Biswas, A.; Maiti, S. and Bhattacharya, A. (2013) Shoreline changes in response to sea level rise along Digha Coast, Eastern India: an analytical approach of remote sensing, GIS and statistical techniques. J Coast Conserv 17 (4).

https://www.jstor.org/stable/24760636?seq=1

17-Lu, D.; Mausel, P.; Brondizios, E. and Moran, E. (2004) Change detection techniques. Int J Remote Sens 25:2365-2407.

https://www.tandfonline.com/doi/abs/10.1080/0143116031000139863

18-Magesh, S.; Chandrasekar, N. and Kaliraj, S. (2014) Mapping the coastal geomorphological landforms through Aster DEM and Landsat data - a case study from Tuticorin-Vembar coastal stretch, southeast coast of India. J Coastal Sci 1 (1).

https://figshare.com/articles/journal_contribution/Mapping_the_coasta 1_geomorphological_landforms_through_Aster_DEM_and_Landsat_d ata_a_case_study_from_Tuticorin_Vembar_coastal_stretch_southeast _coast_of_India/1010148

19-Mahmoudi, P.; Shirazi, S.; Firoozi, F.; Jahanshahi, S. and Mazhar, N. (2020) Detection of land cover changes in Baluchistan (shared between Iran, Pakistan, and Afghanistan) using the MODIS Land Cover Product. Arabian Journal of Geosciences 13: 1274 https://link.springer.com/article/10.1007/s12517-020-06284-9 
20-Marghany, M.; Sabu, Z. and Hashim, M. (2010) Mapping coastal geomorphology changes using synthetic aperture radar data. Int J Phys Sci 5 (2):1890-1896.

https://www.researchgate.net/publication/228894961_Mapping_coasta 1_geomorphology_changes_using_synthetic_aperture_radar_data

21-McFeeters, K. (1996) The use of the Normalized Difference Water Index (NDWI) in the delineation of open water features. Int J Remote Sens 17 (7). https://www.tandfonline.com/doi/abs/10.1080/01431169608948714

22- Milan, J.; Heritage, G.; Large, A.; and Fuller, I. (2011) Filtering spatial error from DEMs: Implications for morphological change estimation. Geomorphology, V. 125, Issue 1, PP 160-171 https://www.sciencedirect.com/science/article/abs/pii/S0169555X100 04058?via\%3Dihub

23-Mujabar, S.P. and Chandrasekar, N., (2011) Landform dynamics along the southern coastal Tamil Nadu of India by using remote sensing and GIS. Geo-spat. Inf. Sci.14 (4), 282-293.

24-Nofal, R. and Abboud, I. (2016) Geomorphological evolution of marine heads on the eastern coast of Red Sea at Saudi Arabian region, using remote sensing techniques. Arab J Geosci 9:163.

https://www.infona.pl/resource/bwmeta1.element.springer-doi10_1007-S12517-015-2234-4

25-Omran, E. and Frihy, O. (2017) Evaluation of future land-use planning initiatives to shoreline stability of Egypt'snorthernNiledelta. Arab J Geosci 10: 109 https://link.springer.com/article/10.1007/s12517-017-2893-4

26- Page, L. and Thorp, V. (2010) Tasmanian Coastal Works Manual: A best practice management guide for changing coastlines. Department of Primary Industries, Parks, Water and Environment, Tasmania. https://dpipwe.tas.gov.au/Documents/Tasmanian_Coastal_Works_Manual.pdf

27-Pattanaik, A,; Sahu, K. and Bhutiyani, M. (2015) Estimation of shallow water bathymetry using IRS-multispectral imagery of Odisha Coast, India. Aquatic Procedia 4:173-181. https://www.sciencedirect.com/science/article/pii/S2214241X15000255

28-Shaban, R.; Aldhshan, S.; Zulhaidi, H. and Shafri, M. (2019) Change detection on land use/land cover and land surface temperature using spatiotemporal data of Landsat: a case study of Gaza Strip. Arabian Journal of Geosciences 12: 443 https://link.springer.com/article/10.1007/s12517-019-4597-4 
29-Skilodimou, H.; Th.Stefou1i, M. and Bathrellos,G. (2002) Spatiotemporal analysis of the coastline of Faliro Bay, Attica, Greece. Estudios Geol., 58: 87-93

http://estudiosgeol.revistas.csic.es/index.php/estudiosgeol/article/view 1113

30-Siart, C.; Bubenzer, O. and Eitel, B. (2009) Combining digital elevation data (ASTER/SRTM), high resolution satellite imagery (Quickbird) and GIS for geomorphological mapping: a multicomponent case study on Mediterranean karst in Central Crete. Geomorphology 112:106-121.

https://www.sciencedirect.com/science/article/abs/pii/S0169555X090 $\underline{02189}$

31-Singh, A. (1989) Digital change detection techniques using remotely sensed data. Int J Remote Sens 10:989-1003.

https://www.scirp.org/(S(czeh2tfqyw2orz553k1w0r45))/reference/Ref erencesPapers.aspx?ReferenceID $=1598994$

32-Stow, A. (1999) Reducing mis-registration effects for pixel-level analysis of land-cover change. Int J Remote Sens 20:2477-2483.

33-Stumpf, P.; Holderied, K. and Sinclair, M. (2003) Determination of water depth with high-resolution satellite imagery over variable bottom types. Limnology Oceanography 48:547-556. https://aslopubs.onlinelibrary.wiley.com/doi/abs/10.4319/1o.2003.48.1 part_2.0547

34-Thieler, R.; Himmelstoss, A.; Zichichi, J. and Ayhan, E. (2017) Digital Shoreline Analysis System (DSAS) version 4.0 - An ArcGIS extension for calculating shoreline change (ver.4.4, July 2017): U.S. Geological Survey Open-File Report 2008-1278. https://www.usgs.gov/centers/whomsc/science/digital-shorelineanalysis-system-dsas?qt-science_center_objects=0\#qtscience_center_objects

35- Trab, M. (1984) Umm Rakham area - in the west of Marsa Matrouh Between Wadis of Umm Ashtan and Alhas. Geomorphological study in Arabic, MA, Alexandria). 


\section{ملخص}

منطقة الدراسة جزء من الساحل الثمالي الغربي لمصر وتمتد إلى الغرب من

مدينة مطروح لمسافة 10 كم فيما بين خليج أم الرخم ورأس العاصي. تتميز هذه المنطقة بتتوع اشكال سطح الأرض الساحلية مثل الرؤوس والخلجان والكثبان الرملية والثروم وغيرها. نظراً لتعرض بعض أجزاء هذه المنطقة للتآكل الثديد، فقد تمت دراسة المتغيرات المورفولوجية السائدة التي تؤثر على اشكال سطح الأرض الساحلية. وأكدت النتائج الدور الفعال الذي تلعبه الأمواج والتيارات الثاطئية في تطور منطقة الثاطئ القريب والثاطئ الأمامي والثاطئ الخلفي، بينما لوحظ ثأثنر الرياح في منطقة الكثبان الرملية.

تم استخدام تقنيات الاستشعار عن بعد ونظم المعلومات الجغرافية لكثف التغير في اشكال سطح الأرض الساحلية، ومن أجل رصد هذه التغييرات، نم استخدام صورتين من نوع لاندسات بينهما فنرة زمنية. سب سنة. وأظهرت النتائج أن منطقة الثاطئ القريب وخط الثاطئ هي الأكثر عرضه لخطر عمليات التعرية بفعل قوة وسرعة التيارات الساحلية. كما تم رصد التغيير في الغطاء الأرضي في نطاق الثاطئ الخلفي.

بمقارنة نموذجين من نماذج الارتفاع الأرضي بفاصل زمني 11 سنة، أظهرت ان بعض اشكال سطح الأرض شهدت تغيرات رأسية خاصة في مناطق الكثبان الرملية والثروم. 